\title{
Effect of Micronutrient on Plant Growth and Flowering of Tomato (Solanum lycopersicum L.) cv. Vijeta
}

\author{
Smita Kumari* and Kumari Sarika
}

Department of Horticulture, School of Agriculture, Lovely Professional University, Jalandhar, Punjab, India

*Corresponding author

\section{Keywords}

Tomato, vijeta, micronutrients, growth and development

Article Info

Accepted:

12 March 2021

Available Online:

10 April 2021
The present investigation entitled "Effect of micronutrients on plant growth and flowering of tomato (Solanum lycopersicum L.) cv. vijeta was under taken at vegetable research field, Department of Horticulture, School of Agriculture, Lovely Professional University (Jalandhar) during rabi season (2018-19). The experiment was laid out in Randomized block design with 13 treatments. The treatments consist of different combinations of micronutrients i.e., zinc, boron, copper and iron. Among these thirteen treatments, treatment $\mathrm{T}_{12}\left(\mathrm{ZnSO}_{4}+\mathrm{B}_{3} \mathrm{HO}_{3}+\mathrm{CuSO}_{4}+\mathrm{FeSO}_{4} @ 600 \mathrm{ppm}\right)$ was recorded the maximum plant height $(140.50 \mathrm{~cm})$, minimum days to first flowering (26.20), highest no. of flower clusters (10.50), highest no. of flowers per cluster (8.62), followed by treatment $\mathrm{T}_{11}\left(\mathrm{ZnSO}_{4}+\mathrm{B}_{3} \mathrm{HO}_{3}\right.$ $+\mathrm{CuSO}_{4}+\mathrm{FeSO}_{4} @$ 300ppm).

\section{Introduction}

Tomato is an important vegetable fruit crop grown in India as well as world. It is also known as Wolf apple or Love of Apple, originated in peru, brought by portugese in India. It occupies second position in terms of area after potato and $1^{\text {st }}$ position in processing. It is self pollinated crop and requires temperature range of $25^{\circ} \mathrm{C}$ to $29^{\circ} \mathrm{C}$ for growing (Ejaz et al., 2011). Different fruit ingredients like soup, salad, ketchup, puree are prepared. On the basis of nutrition $100 \mathrm{~g}$ tomato holds $48 \mathrm{mg} \mathrm{Ca}, 27 \mathrm{mg}$ ascorbic acid, $0.9 \mathrm{~g}$ proteins, $0.8 \mathrm{~g}$ fibre etc. Besides, this nutritional component, tomato also contain lycopene that favours colour of tomato. It helps in keeping of blood vessel in healthy conditions (Ejaz et al., 2011).

Tomato is the rich source of sugar, starch, major and minor micro-nutrients and also contains organic, citric and acetic acids. Even flavouring of tomato is controlled by volatile 
compounds. Micronutrients have an important role in the plant activities and foliar application can improve the quality and quantity of tomato (Ali et al., 2012) by increasing photosynthesis of green plants (Singh and Tiwari, 2013).

Among micronutrients, $\mathrm{Zn}$ and $\mathrm{B}$ are important for plant nutrition. Tomato requires both major and micronutrients for its proper plant growth (Pandita et al., 1976). Zn plays important role on growth and development as well as carbohydrates, protein metabolism and sexual fertilization of plants (Chung et al., 1997 and Mehdizadeh et al., 2013) while B deficiency reduced yield and quality in tomatoes (Bajpai et al., 2001). Balanced fertilization of macro and micro nutrients can increase production (Hatwar et al., 2003 and Yassen et al., 2010) but foliar application of micronutrients is the not only efficient but also secured way (Schwarz et al., 2010).

The most easily observed symptom of iron deficiency in plants is extensive chlorosis in the leaves (Chanda et al., 2011). The role of boron in the formation of chlorophyll in plants was well established. The zinc deficiency in tomato causes decrease in rate of protein synthesis, reduction in shoot growth and finally yields.

Thus, micronutrients as their requirement is low but they are essential as the larger amount of primary and secondary nutrients for plant growth and development. Keeping in view all the above facts an experiment has been conducted to access the micro-nutrient analysis on plant growth, flowering and yield of tomato of various treatment combinations.

\section{Materials and Methods}

An experiment was carried out at vegetable research field, Department of Horticulture, School of Agriculture, Lovely Professional
University (Jalandhar) during rabi season (2018-19). The experiment was completed in RBD with 13 treatments and each replicated thrice.

\section{Results and Discussion}

\section{Growth Parameters}

The data revealed that the combination of different micronutrients affected growth parameter showed the significant difference in plant height due to application of different treatment combination of micronutrients.

The treatment $\mathrm{T}_{12}\left(\mathrm{ZnSO}_{4}+\mathrm{B}_{3} \mathrm{HO}_{3}+\mathrm{CuSO}_{4}\right.$ + $\mathrm{FeSO}_{4} @ 600$ ppm) recorded the maximum plant height $(140.50 \mathrm{~cm})$, followed by $\mathrm{T}_{11}$ $\left(\mathrm{ZnSO}_{4}+\mathrm{B}_{3} \mathrm{HO}_{3}+\mathrm{CuSO}_{4}+\mathrm{FeSO}_{4} @ 300\right.$ ppm), with $132.72 \mathrm{~cm}$ which differed significantly from each other as well from other treatment. Maximum plant height shown by 120 DAT in tomato. In this research paper $\mathrm{ZnSO}_{4} @ 300$ and 600 ppm show 105.55 and $119.91 \mathrm{~cm}$ respectively; Boric acid @ 300 and $600 \mathrm{ppm}$ emphasis height of 118.66 and $127.00 \quad \mathrm{~cm}$ respectively; CopperSulphate@100ppm and 300 ppm 116.00 and $117.16 \mathrm{~cm}$.

At height in the treatments $\mathrm{T}_{12}$ and $\mathrm{T}_{11}$ might be due to the spray of micronutrients might have improved the soil physical and chemical properties and leading to the adequate supply of nutrients to the plants which might have promoted the maximum vegetative growth while the minimum plant growth was due to non-availability of micronutrients. Similar findings were reported by (Parry et al., 2007) in tomato and (Bid et al., 1992) in brinjal.

\section{Flowering parameters}

The data revealed that the combination of different micronutrients affected various flowering parameters of tomato. 
Table.1 Performance of Growth parameters of Tomato PKM-1 Variety due to effect of different micronutrients combinations

\begin{tabular}{|c|c|c|c|c|c|c|c|c|c|}
\hline & \multicolumn{4}{|c|}{ Plant height } & \multicolumn{2}{c|}{$\begin{array}{c}\text { No. of flower } \\
\text { clusters }\end{array}$} & \multicolumn{2}{c|}{$\begin{array}{c}\text { No. of flowers/ } \\
\text { cluster }\end{array}$} & $\begin{array}{c}\text { Days to } \\
\text { flowering }\end{array}$ \\
\hline & 30 DAT & $\begin{array}{c}60 \\
\text { DAT }\end{array}$ & 90 DAT & $\begin{array}{c}120 \\
\text { DAT }\end{array}$ & $\begin{array}{c}45 \\
\text { DAT }\end{array}$ & DAT & 45 DAT & 75 & \\
\hline Control & 49.19 & 78.25 & 91.56 & 105.55 & 4.20 & 5.78 & 2.87 & 4.23 & 41.05 \\
\hline ZincSulphate@300ppm & 58.63 & 86.32 & 97.00 & 119.91 & 5.00 & 6.16 & 4.66 & 5.10 & 37.66 \\
\hline ZincSulphate@600ppm & 59.71 & 92.33 & 103.00 & 123.50 & 6.00 & 6.63 & 4.83 & 5.76 & 35.66 \\
\hline Boricacid@300ppm & 58.00 & 88.66 & 98.33 & 119.66 & 5.00 & 6.50 & 4.43 & 5.40 & 35.00 \\
\hline Boricacid@600ppm & 58.33 & 92.66 & 104.33 & 127.00 & 6.66 & 7.33 & 5.33 & 6.16 & 34.66 \\
\hline $\begin{array}{c}\text { CopperSulphate@100pp } \\
\text { m }\end{array}$ & 58.33 & 92.66 & 104.33 & 116.00 & 4.33 & 5.66 & 3.66 & 4.50 & 39.00 \\
\hline $\begin{array}{c}\text { CopperSulphate@300pp } \\
\text { m }\end{array}$ & 55.00 & 86.00 & 98.00 & 117.16 & 4.66 & 6.00 & 4.00 & 4.90 & 38.33 \\
\hline $\begin{array}{c}\text { FerrousSulphate@300pp } \\
\text { m }\end{array}$ & 55.00 & 86.00 & 98.00 & 117.16 & 4.66 & 6.00 & 4.00 & 4.90 & 38.33 \\
\hline $\begin{array}{c}\text { FerrousSulphate@600pp } \\
\text { m }\end{array}$ & 48.85 & 82.68 & 95.88 & 107.71 & 3.89 & 5.12 & 2.98 & 4.20 & 37.71 \\
\hline $\begin{array}{c}\text { Zinc+Boron+Copper@30 } \\
\text { 0ppm }\end{array}$ & 51.55 & 82.61 & 94.51 & 115.78 & 4.23 & 5.57 & 3.84 & 4.68 & 39.00 \\
\hline $\begin{array}{c}\text { Zinc+Boron+Copper@60 } \\
\text { 0ppm }\end{array}$ & 61.55 & 92.71 & 105.91 & 128.71 & 6.00 & 6.33 & 5.61 & 5.11 & 33.33 \\
\hline $\begin{array}{c}\text { Zinc+Boron+Copper+Fe } \\
\text { rrous@300ppm }\end{array}$ & 63.33 & 95.33 & 116.00 & 132.70 & 7.33 & 8.66 & 6.10 & 7.10 & 30.00 \\
\hline $\begin{array}{c}\text { Zinc+Boron+Copper+Fe } \\
\text { rrous@600ppm }\end{array}$ & 65.00 & 97.66 & 121.33 & 140.50 & 8.00 & 10.50 & 6.50 & 8.62 & 26.20 \\
\hline
\end{tabular}

The treatment $\mathrm{T}_{12}\left(\mathrm{ZnSO}_{4}+\mathrm{B}_{3} \mathrm{HO}_{3}+\mathrm{CuSO}_{4}\right.$ $+\mathrm{FeSO}_{4} @ 600$ ppm) showed the minimum days to first flowering after transplanting (26.20), maximum number of flower clusters per plant (10.50) and maximum number of flowers per cluster (8.62). The earliness to flowering in treatment $T_{12}$ might be due to the better spray of micronutrients to the aerial parts. Similar findings were reported by (Day, 2000) in tomato.

\section{Acknowledgment}

The author wishes to thank the Lovely Professional University, financially supporting this Research.

\section{Abbreviations}

$\mathrm{ZnSO}_{4}$-Zinc Sulphate
$\mathrm{CuSO}_{4}$ - Copper Sulphate

$\mathrm{FeSO}_{4}$-Ferrous Sulphate

$\mathrm{B}_{3} \mathrm{HO}_{3}$-Boric Acid

\section{References}

Ali, W., Jilani, M. S., Naeem, N., Waseem, K., Khan, J., \& Ahmad, M. J. (2012). Evaluation of different hybrids of tomato under the climatic conditions of Peshawar. Sarhad Journal of Agriculture, 28(2).

Arahunashi, C. S. (2011). Influence of organics on growth, yield and quality of tomato (Lycopersicum esculentum L. Mill.) (Doctoral dissertation, UAS, Dharwad).

Bajpai, S., \& Chauhan, S. V. S. (2001). Effect of zinc, boron and manganese on yield in okra (Abelmoschus esculentus). 
Indian Journal of Agricultural Science, 71(5), 332-333.

Bhatt, L., Srivastava, B. K., \& Singh, M. P. (2004). Studies on the effect of foliar application of micronutrients on growth, yield and economics of tomato (Lycopersicon esculentum Mill). Prog. Hort, 36(2), 331-334.

Bid, N. N., De, A. K., Srivastava, B. K., \& Kole, K. K. (1992). Response of micronutrients, zinc and copper on brinjal (Solanum melongena L.). In Proceedings of the Workshop on Micronutrients (pp. 22-23).

Chanda, G. K., Bhunia, G., \& Chakraborty, S. K. (2011). The effect of vermicompost and other fertilizers on cultivation of tomato plants. Journal of Horticulture and Forestry, 3(2), 42-45.

Chung, H. D., Youn, S. J., \& Choi, Y. J. (1997). Effects of rootstocks on yield, quality and components of tomato fruits. Journal of the Korean Society for Horticultural Science (Korea Republic).

Davis, J. M., Sanders, D. C., Nelson, P. V., Lengnick, L., \& Sperry, W. J. (2003). Boron improves growth, yield, quality, and nutrient content of tomato. Journal of the American Society for Horticultural Science, 128(3), 441446.

Day, S. C. (2000). Tomato crop in vegetable growing. Agrobios, New Dehli, India, 59-61.

Ejaz, M., Rehman, S. U., Waqas, R., Manan, A., Imran, M., \& Bukhari, M. A. (2011). Combined efficacy of macronutrients and micro-nutrients as foliar application on growth and yield of tomato grown by vegetable forcing. International Journal for Agro Veterinary and Medical Sciences, 5(3), 327-335.

Hatwar, G. P., Gondane, S. M., \& Urkade, S. M. (2003). Effect of micronutrients on growth and yield of chilli.

Kah, M., \& Hofmann, T. (2014). Nanopesticide research: current trends and future priorities. Environment international, 63, 224-235.

Mehdizadeh, M., Darbandi, E. I., Naseri-Rad, H., \& Tobeh, A. (2013). Growth and yield of tomato (Lycopersicon esculentum Mill.) as influenced by different organic fertilizers. International journal of Agronomy and plant production, 4(4), 734-738.

Mohammed, H. M., Prasad, V. M., Thomas, T., \& Kispotta, W. (2014). Effect of organic and inorganic on growth and economic of tomato (Lycopersicon esculentum Mill.) cv. heem sohna under protected cultivation. International Journal of Agricultural Science and Research (IJASR), 4(2), 67-77.

Naz, F., Haq, I. U., Asghar, S., Shah, A. S., \& Rahman, A. (2011). Studies on growth, yield and nutritional composition of different tomato cultivars in Battal valley of district Mansehra, Khyber Pakhtunkhwa, Pakistan. Sarhad J. Agric, 27(4), 569-571.

Randhawa, K. S., \& Singh, D. (1976). effect of certain growth influencing substances and sowing techniques on the vegetative growth, sex ratio, early and total yields of bottle gourd (Lagenaria siceraria (Mol.) Standl.). J Res Punjab Agric Univ.

Schwarz, D., Rouphael, Y., Colla, G., \& Venema, J. H. (2010). Grafting as a tool to improve tolerance of vegetables to abiotic stresses: Thermal stress, water stress and organic pollutants. Scientia Horticulturae, 127(2), 162171.

Singh, H. M., \& Tiwari, J. K. (2013). Impact of micronutrient spray on growth, yield and quality of tomato (Lycopersicon esculentum Mill). HortFlora Research 
Spectrum, 2(1), 87-89.

Stout, P. R., \& Arnon, D. I. (1939).

Experimental methods for the study of the role of copper, manganese, and zinc in the nutrition of higher plants. American Journal of Botany, 144-149.
Yassen, A. E. A. A., EAA, A. E. N., \& Shedeed, S. (2010). Response of wheat to foliar spray with urea and micronutrients. Journal of American Science, 6(9), 14-22.

\section{How to cite this article:}

Smita Kumari and Kumari Sarika. 2021. Effect of Micronutrient on Plant Growth and Flowering of Tomato (Solanum lycopersicum L.) cv. Vijeta. Int.J.Curr.Microbiol.App.Sci. 10(04): 395-399. doi: https://doi.org/10.20546/ijcmas.2021.1004.042 